\title{
A Best Evidence Analysis and Synthesis of Research on Teacher Mentoring Programs for the Entry Year Teacher in the Public Elementary and Secondary Schools
}

Linda Cernetic

Cedarville University

Follow this and additional works at: http://digitalcommons.cedarville.edu/education_theses

Part of the Teacher Education and Professional Development Commons

\section{Recommended Citation}

Cernetic, Linda, "A Best Evidence Analysis and Synthesis of Research on Teacher Mentoring Programs for the Entry Year Teacher in the Public Elementary and Secondary Schools" (2003). Master of Education Research Theses. 32.

http://digitalcommons.cedarville.edu/education_theses/32 


\title{
A BEST EVIDENCE ANALYSIS AND SYNTHESIS OF RESEARCH ON TEACHER MENTORING PROGRAMS FOR THE ENTRY YEAR TEACHER IN THE PUBLIC ELEMENTARY AND SECONDARY SCHOOLS
}

\author{
A thesis submitted in partial fulfillment \\ of the requirements for the degree of \\ Masters of Education
}

By

LINDA K. CERNETIC

B.S., Wright State University, 1977

2002

Cedarville University 


\section{CEDARVILLE UNIVERSITY}

SCHOOL OF GRADUATE STUDIES

May 1,2003

I, HEREBY RECOMMEND THAT THE THESIS PREPARED UNDER MY SUPERVISION BY Linda K. Cernetic ENTITLED A Best Evidence Analysis and Synthesis of Research on Teacher Mentoring Programs for the Entry Year Teacher in the Public Elementary and Schools BE ACCEPTED IN PARTIAL FULFILLMENT OF THE REQUIREMENTS FOR THE DEGREE OF Master of Education.

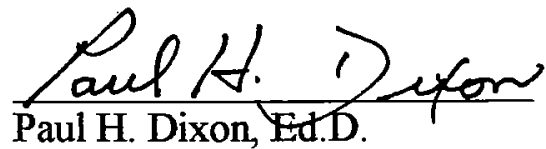

President

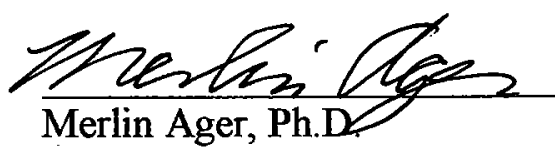

Dean, School of Social Sciences and Professional Studies

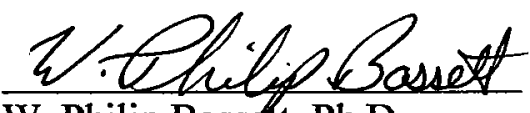

W. Philip Bassett, Ph.D.

Education Department Chair
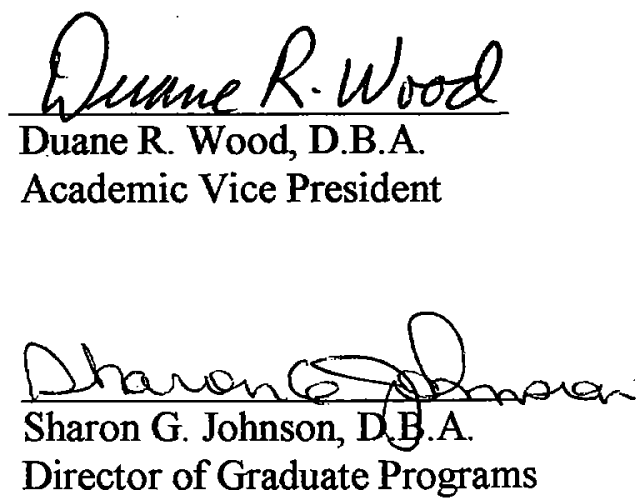

Director of Graduate Programs

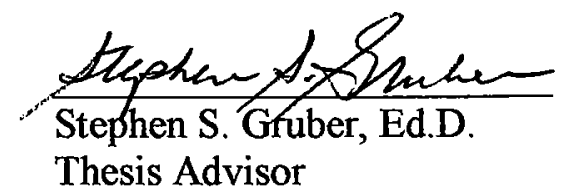




\begin{abstract}
Cernetic, Linda K. M. Ed., Education Department, Cedarville University, 2002.

A Best Evidence Analysis and Synthesis of Research on Teacher Mentoring Programs for the Entry Year Teacher in the Public Elementary and Secondary Schools

A best evidence analysis and synthesis of research on teacher mentoring programs culminating in an open ended survey to teachers that have received Pathwise training in preparation for mentoring of entry year teachers in a large city school in Ohio. The surveys asked whether the mentors felt that formal mentor training improved their skills as a mentor. The outcome determined by this research is that it is beneficial.
\end{abstract}




\section{ACKNOWLEDGEMENTS}

I want to thank my Lord and Savior, Jesus Christ who has given me the wisdom and continued support to complete this Masters program at Cedarville University, without Him I never would have been allowed to be a part of this university.

My family that has lived through this with me, always hearing, I will do this or that, but not until I finish my research. Faith and Michaela, my daughters at home, you have put up with much, thanks for all your help and I love you.

Thank you Dr. Gruber for your constant encouragement while I waded through this paper. When I started I really didn't know if I would complete this, it seemed so big, you took me through piece-by-piece allowing me to get past the big picture.

Dr. Ed Baumann you taught this new Christian to really begin to look at the world through a Christian worldview. I sometimes even find myself reading philosophy books for fun. Your truly encouraged me with your honesty and willingness to accept me where I was when I turned in work to you.

Dr. Phil Bassett, Dr. Johnson and those involved in any way with this graduate program. your encouragement through my mother's illness really kept me in the program.

To my proofreader, you know who you are, thanks doesn't seem enough. Thanks for supporting me when I needed a pick me up.

To all my unnamed friends and co-workers that have encouraged me along the way these past few years, through the illness and death of my mother, planning of a wedding and endless time spent on bleachers while we cheered the home team and our daughters. Thanks. 


\section{DEDICATION}

I want to dedicate this thesis to my best friend, the one who is always and has always been my cheerleader, and the one who tells me I can when I am thinking the exact opposite, my husband, Bill Cernetic. Without his love, encouragement, support, and prayers, I would not have been able to complete this huge task. Thank you, Bill for believing in Him and me. I love you. 


\section{TABLE OF CONTENTS}

Page

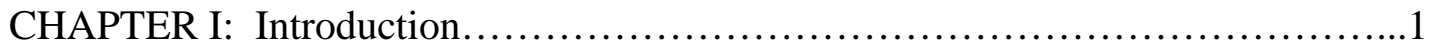

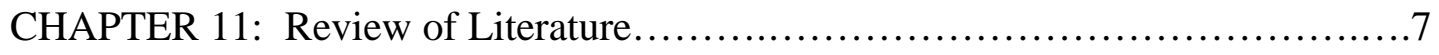

CHAPTER III: Procedures and Results.........................................44

Presentation of the Problem.............................................44

Presentation of Hypothesis............................................45

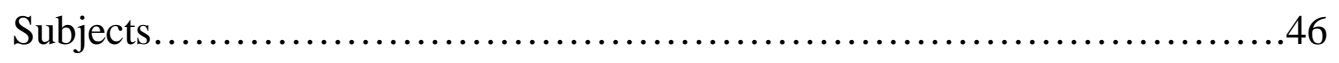

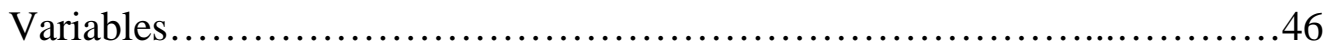

Procedures......................................................... 47

Results................................................................. 47

CHAPTER IV: Summary and Conclusions....................................55

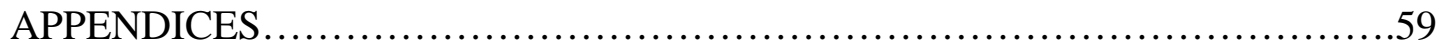

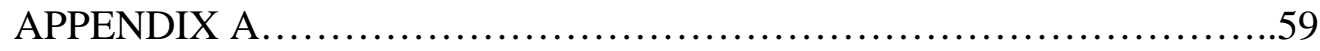

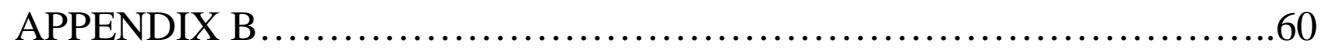

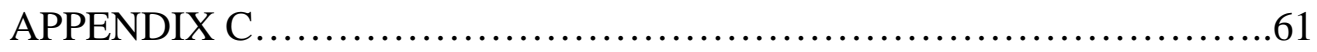

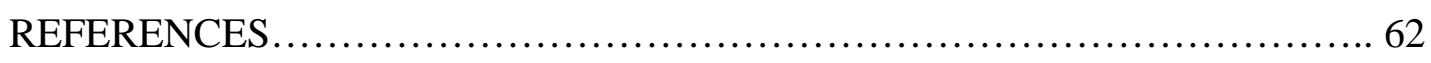

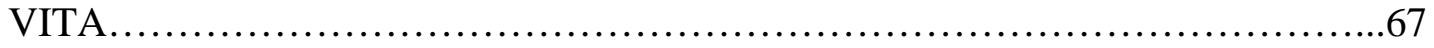




\section{CHAPTER I: Introduction}

\section{Educational Significance}

The teaching profession is facing a crisis in the coming five to ten years as many experienced teachers reach the age of retirement. The challenge facing public schools will be the ability to keep the beginning teacher in the field after just a few years of experience. Ohio is one of many states changing the requirements for a student in teacher education to not only get their initial teaching license but to have one converted to a five year license. In Ohio, as in many other states, part of this requirement is that an experienced teacher will mentor the entry year teacher during the first year of teaching. For the purpose of this study an entry year teacher is defined as a teacher in their first year of teaching and/or in their first year of teaching in the school district of employment. The quality of the mentoring program could be a key factor in the entry year teacher's success or failure not only in the first year but also in subsequent years. The questions being asked in this research are: What are the components of an effective mentoring program? How will a successful mentoring program benefit the teaching profession and education in today's public school? How important is it to the success of a mentoring program that the mentor be required to have formal training prior to becoming a mentor?

The mentoring program should be designed to act as a safety net for the entry year teacher. Mentoring is planned to encourage new teachers as they make the transition from student teaching to being teachers of students. In the past a new teacher was often given a buddy teacher to guide them in the control beliefs of their buildings and the school district 
where they were employed. This type of mentoring is sometimes referred to as "first generation mentoring." The collegiality of the faculty and politics of a building are determined historically by those who have been on the faculty the longest; it was the buddy teacher's responsibility to inform the new teacher of these so that they would get along with everyone. Examples of this are where to eat lunch and who to avoid when upset about something happening in the building. This buddy teacher was not expected to evaluate or guide the new teacher in the methods of teaching; it was assumed that this had been accomplished in the university or teachers college. Students in the education classes at the universities are required to pass written tests, take methods classes, which may or may not require classroom experiences and finish their programs with a quarter or semester of student teaching. In the past a mentor was to be as the term buddy teacher implied a buddy or a friend.

\section{Purpose of the Study}

The focus of this research is on "second generation mentoring" (The National Foundation for the Improvement of Education, 1999. p. 7). The mentor of today will play a vital role in the entry year teacher's future as a teacher. The mentor of the twenty first century will be required to be an extension of the training given prior to entering the teaching profession. For example, Ohio's new Teacher Education and Licensure Standards charge the teacher mentoring the entry year teacher with the responsibility to have the entry year teacher ready to pass the Professional Assessment for Beginning Teachers (PRAXIS III) by February of their first year of teaching. Public school districts in Ohio will be required to have an entry year program in place with the beginning of the 2002-2003 school year. The mentor in 
a structured mentoring program will enable the first year teacher to have the skills needed to pass the PRAXIS III observation. School districts will be required to have teachers willing to take on the responsibility and be knowledgeable in the new laws when they begin to implement a mentoring program within their own districts. Researching other mentor or entry year teacher programs will supply district Continuous Improvement Planning (CIP) teams with data indicating what has been successful and less than successful in other similar programs in the area of mentor training. As a member of the District Wide Mentoring Committee for the past four years in a large city school district in southwestern Ohio and having spent two of those years as one of two lead mentors for the district this researcher has a personal interest in the research of mentoring programs. In the academic year beginning in August 2002, the committee's years of planning will become reality as this school system begins its first year in control of the mentoring program that for the past four years has been a part of the Pilot Program controlled by the local Educational Service Center. The research will benefit this work as it is compared to the plan that has been developed for the abovementioned school district.

\section{Research Methodology}

The research method used to investigate previous studies available on mentoring programs will be completed using a best evidence analysis and synthesis. "It combines the quantification and systematic literature search methods of quantitative syntheses with the attention to individual studies and methodological and substantive issues typical of the best narrative reviews" (Slavin, 1986, p. 5). The researcher used this method because although this was primarily a review and analysis of qualitative research this allowed the researcher to 
incorporate quantitative studies into this project. The method used to track the research as it was reviewed was a numbering system with notes being kept in a word processing program for flexibility when assembling the data upon completion of the research. Documents were sorted using a five-point Likert scale according to the relativity they had to the research and the credibility of the authors.

\section{Sources}

There is a wealth of information available in recent issues of Journal of Career Development, Teaching and Teacher Education, Journal of Vocational Behavior, Journal of Instructional Psychology and other journals dedicated primarily to the education profession on mentoring and entry year programs. The research was conducted primarily through reading and summarizing of journal articles, books and various scholarly papers on the components of a successful mentoring program. Personal interviews were conducted with professionals that have been using entry year programs within their districts prior to the fall of 2002. Grants have been used to pilot entry programs and professionals involved with one of these programs was also interviewed. Mentoring of entry year teachers is a recent method being used in schools today and at this date the researcher has not located any longitudinal studies on this subject appropriate for this research.

Literature reviews covered current as well as older research found through extensive searches on the World Wide Web. Professional organizations, departments of education, and local school districts where mentoring is already a part of the entry year program provided validity to the necessary components of a successful mentoring program in this research. The library was a source of historical and current books written on this topic. Scholarly 
papers on this subject were found by searching the World Wide Web and OhioLINK databases available in the library. Research previously conducted at Virginia Polytechnic Institute and State University by Wildman, Magliaro, Niles and Niles, Allen and Poteet, who have spent much time researching mentoring from not only the mentors but the mentees viewpoint along with the employer, are just a small part of the research being reviewed in this current qualitative analysis. Boreen and Niday have not only written numerous journal articles they have also published a guidebook for mentoring that was reviewed for this research.

For the purpose of this research the terms protégé, first year teacher, novice teacher, mentee and entry year teacher are equivalent terms all referring to the teacher that is their first year of employment in the teaching profession.

\section{Biblical Integration}

Mentoring is part of being a Christian; a Christian is expected to disciple and guides others by their actions in their Christian worldview. Often it is not what a Christian speaks, but their actions that have a greater impact on their co-workers and students. It is the same in mentoring. A mentor is not only expected to teach a new teacher through words how to be an effective teacher but through modeling the behaviors in their classrooms. The new teachers will watch their mentor just as the Christian is watched by unbelievers to see if their walk matches their talk. How the mentor behaves in the teachers' lounge with co-workers is just as important as it is to the Christian to be aware of what types of conversation they allow themselves to be involved with in the same setting. "Mentors are individuals who have guided, sponsored, or otherwise had a positive and significant influence on the professional 
career development of another employee" (Allen \& Poteet, 1999, p. 62). The same quote can also be said of Christians substituting the word mentor for disciple and professional career for a Christian's walk with the Lord. In Luke 6:40 (New King James Version) the Bible tells us that, "A disciple is not above his teacher, but everyone who is perfectly trained will be like is teacher." Proverbs 22:6 (NKJV), a well-known verse to Christians, "Train up a child in the way he should go, and when he is old he will not depart from it" is a charge to parents. A mentor is charged with the same responsibility in regards to guiding a beginning teacher through the first year of teaching.

\section{Treatment}

A component of the mentoring program for the district being used in this study requires the mentor to have formal training in both Pathwise and Ohio First; these are skills observation techniques that are aligned with PRAXIS III. Mentors previously trained in one or both of these techniques as part of a pilot program run through the Greene County Educational Services Center in Greene County, Ohio were sent an open ended questionnaire asking them to respond to questions relating to how beneficial they felt the mentor training was to the success they felt as a mentor? Did the training make their job easier when relating to the entry year teacher? What about being a mentor do you feel cannot be taught? Do you feel that having had the training required to be a mentor that you experienced professional growth? The above questions are examples of the type of research this researcher was looking for when sending out the questionnaires. 


\section{CHAPTER II: Literature Review}

This researcher is interested in finding what other researchers have found to be important in implementing a successful mentoring program in their school districts. Specifically what has been found to be beneficial in the area of training mentors. How important is it to the success of a mentoring program that the mentor be required to have formal training outside of being an experienced educator to be a successful mentor of new teachers?

Judith Warren Little, Graduate School of Education, University of California, Berkeley has published numerous journal articles on the professional development of teachers. She currently teaches courses in qualitative research methods, organizational and policy contexts of teaching and school reform. She has made presentations to educational professional organizations on mentoring and programs for novice teachers in the state of California. Dr. Little focuses her research on teacher's work and careers, the contexts of teaching and policies and practices of professional development.

Prior to 1983 little research had been done in the area of mentoring new teachers. As states around the country have begun to reform their standards for teachers, mentoring has become an integral part of this reform. Mentoring is thought to be a win, win situation benefiting all involved: the mentor, mentee and school district. "In the mentor

programs that have swept education, the demands on the mentor's competence, character, 
and commitment are often muted, reduced to formal eligibility criteria and specific job descriptions" (Little, 1990, p. 298).

The implementation of mentor programs presents a problem in that teachers are trained to work in isolation and with the title of mentor they are required to work with another teacher sharing their expertise in a manner they were never trained to do when in studying to become a teacher. Mentoring presents an interesting challenge for those who accept the challenge. A classroom teacher becoming a mentor takes on an administrative role in an organization where precedents have been set for this position. (Little, 1990) Studies have shown that there is little to be gained when a program is implemented in haste. "Issues surrounding the criteria and process for selection ha ve consumed a large share of the political and material resources devoted to implementation and have occupied a central place in research" (Little, 1990, p. 305). Without clear criteria for the selection of mentors the position has become more of a political problem than a technical problem. More than classroom expertise should be considered in the selection of teacher to the position of mentor. Many teachers that work well within the confines of their classroom do not possess the skills and the ability to work with their peers that would make them quality mentors.

In an effort to take the selection of mentors out of the internal political arena formal mentor training has become a more common component of mentor programs. (Little, 1990) "Opponents of such training made the case that the very selection of teachers as mentors was intended to signal a high level of professional capacity, whereas advocates of training underscored the unfamiliar demands of mentoring for the which the 
classroom provided little or no preparation" Bird and Little study (as cited in Little, 1990, p 308). Formal training of mentors is more likely to be required when the implementation of a program is closely lined to state mandates and the licensing of teachers. Mentor training is also part of the mentor requirement when mentoring is part of a school district's ongoing continuous improvement plan. A key ingredient to what a novice teacher claims to be a successful mentor does not hinge on training but on visibility and accessibility to the mentee and other teachers in the district. If a mentor spends more time with curriculum and very little with the novice teachers they are not well respected by their colleagues. (Little, 1990)

Time is a key ingredient to what is considered a successful mentor but this can present other problems. In districts where mentors are allowed release time to consult with the novice teacher it is time lost from their own classroom (Little, 1990). Release time budgets intended as a support for the program may turn out to be a burden for mentors. Release time that draws teachers away from primary classroom responsibilities underscores, perhaps ironically, the marginal status of mentoring activity by placing teachers' work with fellow teachers in competition with the fundamental work of the classroom. To fulfill the obligations of mentoring mentors risk compromising other values institutional goals and increasing the strain on themselves as individuals. (Little, 1990)

A teacher, when put in the role of mentor, is assigned to a leadership role that has little or no recognized prior place in the order of the school. A mentor is put into a role that, depending on how the program is structured, will put them in direct opposition to 
their administrative team. A mentor program that is structured to protect the entry year teacher will not require the mentor to report directly to the building administrator. The mentor of the entry year teacher will not do the evaluation on which a contract decision will be placed. "Furthermore, districts or states rarely consider whether newly proposed roles are compatible with or in conflict with existing leadership opportunities" Hart \& Murphy study (as cited in Little, 1990, p. 312). The most important piece of the mentoring program is the relationship between the mentor and the entry year teacher. If the entry year teacher is not open to the concept of mentoring than the success of the mentor will be hindered. A mentor is being asked to change roles throughout the day from one of a teacher when working within their classroom to one of an administrator when working alongside their entry year teacher. Without training this can be a difficult transition to make. Little (1990) states:

In most instances, teachers retain the identities, obligations, perspectives and affiliations of the classroom teacher while adding on, usually temporarily, the perspectives and perquisites of leadership. The ambiguities surrounding mentorship are compounded as teachers attempt to satisfy two sets of role demands that are not always compatible. (p. 315)

When choosing a mentor based on their expertise in teaching there seems to be some disagreement on the knowledge required to be an expert teacher and mentor. For 
example, a teacher that is knowledge able in their content area may not be gifted with the skills to be a mentor without formal training. If the requirements for becoming a mentor are clear and concise this will be less of a problem. The mentor should have met some stringent requirements to become a mentor so all mentors within a district should be operating from the same basic knowledge base pertaining to mentoring. "Where districts closely structure the mentor-protégé relation and where that relation is tightly coupled to personnel decisions, externally determined priorities and terminology are likely to override mentors' individual preferences and practices" (Little, 1990, p. 317). When this process is used in mentoring the primary purpose will be "to produce skilled performance" (p. 317). Opposite to this way of mentoring is one that is more open ended, allowing for a freer sharing of knowledge between the mentor and protégé. This type allows for more give and take in the mentoring relationship but also requires the district to have the ability to think outside the box because in this type of relationship there is little observable behavior to be labeled and monitored.

Once a mentor has been assigned "proponents of mentoring take for granted that properly selected mentors will be a source of expert knowledge to others" (Little, 1990, p. 318). Teachers, as previously stated, have been trained to work in isolation and often do not have the skills or the desire to share their knowledge with a novice teacher. It is “expected that mentoring relations would be most likely to bear fruit where commitments to individual autonomy were weak" (p. 319). In a building with a high level of collegiality among its staff the mentoring relationship is also more likely to flourish. 
The authors of the journal article "Quality induction: an investment in teachers" are executive and associate directors at the New Teacher Center at the University of California in Santa Cruz, California. The authors see a real need for quality induction programs to support the flood of new teachers expected in the next ten years. "Induction programs, virtually unknown two decades ago, carry a weighty burden of responsibility" (Moir \& Gless, p. 109). It is the opinion of Moir and Gless (2001) that the quality of the induction experience has "the potential to frame the future of the teaching profession, as it will be practiced for the next thirty years" (p. 109). Additional research has identified a “crucial link between student achievement and the quality of a teacher's instruction" (p. 109).

A quality induction program will not only offer survival techniques to the new teacher but also a vision of their future in the education profession. When planning a mentoring program, the school district needs to have a clear picture of what they see happening in the future to prepare their teachers to fit their vision of the future. The school district must have a strong commitment to the program to make it successful. "Institutional commitment can be demonstrated by designing programs that ensure adequate time and resources for new teacher learning and mentor development, by establishing policies that protect the new teacher during the critical stage of induction, and by making teacher development the centerpiece of educational reform across the district" (Moir \& Gless, p. 111). Moir and Gless (2001) believe that "quality mentoring requires careful selection, training, and on-going support. Mentors must be carefully selected. Not every outstanding classroom teacher is necessarily a talented mentor" (p. 
112). The skills required of a quality mentor are not always the same as those needed to be a quality teacher. Selection of mentors need to have a definite criteria set by the district so teachers are aware of what will be expected before they sign on to mentor a new teacher.

"Clearly-articulated standards of professional practice, such as the California Standards for the Teaching Profession (CTSP), are essential in helping both the novice and their mentor communicate effectively about and keep all eyes focused on high quality teaching and increased student learning" (Moir \& Gless, p. 112). The standards set by the state should be used as a guide when planning induction programs for new teachers.

A mentor program needs to be well balanced; it is not a one size fits all type of program. "The most effective mentors are those that intimately know the community, schoolsite, and classroom context of their novice partners; this enables them to provide support that is responsive to the assessed, individual needs of their beginning teachers" (Moir \& Gless, p. 113). A time set aside for collaboration with other novice teachers is an important part of the successful mentoring program. Collaboration with other novice teachers helps the new teacher realize that he or she is not in this alone as others are facing some of the same challenges.

In the journal article Teacher mentoring: an analysis of roles, activities, and conditions, the researchers Terry M. Wildman, Susan G. Magliaro, Ruth Anne Niles and 
Jerome A. Niles (1992) set out to analyze the specific roles, activities and conditions that are experienced in a mentoring program. The researchers with the exception of R. A. Niles are professors at Virginia Polytechnic Ins titute and State University in the Department of Curriculum and Instruction, College of Education. Their specialties range from educational psychology, teacher learning, social studies and teacher induction and mentoring program development, assessment and colleague/mentor teacher program development. R. A. Niles is an independent consultant specializing in social studies, teacher learning, teacher induction and mentor program development. This research centered on mentoring in a school setting for new teachers by experienced mentors as a technique to encourage them to remain in the profession beyond the first year. What qualities does a good mentor have that will help the new teacher in a constructive way as they travel through the first year of teaching? Is a rigid type of mentoring program mandated by a state as a component of teacher reform what is required or are the informal programs set up to meet the needs of an individual school district or building more valuable?

Wildman, Magliaro, Niles, \& Niles, (1992) reported "the results of a qualitative analysis of the responses that 150 mentor teachers gave when asked to describe their activities as mentors and the conditions that promote or hinder their success and (b) to propose a framework for conceptualizing the mentor teacher's role based on their responses" (p. 205). 
The methodology in this research used individual interviews in combination with written response. The questions were appropriate this study. The mentors were in their second year of involvement in the mentor program and were each working with one or two mentees during the 1989-1990 school year. The researchers did not state in their report whether the school system used was public or private and/or the size and location of the district which could have had some bearing on the outcome of their data collection. This researcher feels the data collected is important to this research because it gives feedback on the mentor mentee relationship regardless of the educational setting. The data was analyzed in three stages. The results were grouped into "three general themes in the data: external or contextual factors that impinges on the dyad, mentor characteristics, and beginner characteristics" (Wildman et al., 1992, p. 206).

In the category of mentoring roles and activities the research "identified eight ways of providing assistance to beginners" (Wildman et al., 1992, p. 206). This data was presented with a table that made it clear how the mentors were of assistance. The eight categories identified were:

Direct Professional Assistance

1. Encourage reflection

2. Directing and supporting beginner's actions, plans

3. Providing direct assistance in the development of a process, policy or product, 4. Providing a menu of information and products for beginners' possible use or modification

5. Providing products, ideas that enable beginner to solve a problem 
Direct personal/professional assistance

6. Encouraging/supporting

Indirect personal/professional assistance

7. Beginner contributes to mentor

Interactions extending outside of mentor-beginner dyad

8. Mediating

When it came to contextual factors the key here seemed to be a lack of available time for communication and observation between the mentor and the mentee. The school environment is not set up to be conducive to this type of relationship. When it came to manifesting the eight ways of providing assistance listed above, the key was a willingness to be a mentor in the first place. Also included in this article are the personality characteristics of an ideal mentor. For example a willingness to mentor, sensitive, that is, they know when to back off, helpful, but not authoritarian, emotionally committed to the beginners, astute, diplomatic, able to anticipate problems, nurturing, encouraging, timely in keeping the beginners appraised of their successes, careful to keep the beginners' problems confidential, remains enthusiastic about teaching and a good role model at all times. (Wildman et al. 1992) A priority with the beginner teacher is the ability for the mentor to open up and admit when they need help and to not be afraid to ask questions. When the mentor is a first year mentor there are sometimes more difficulties because that person is just learning how to mentor. 
The researchers concluded that because mentoring is such a personal interaction between the people involved, it is difficult to impose rigid standards on what must and must not be done to meet the need of the beginning teacher. The researchers found that "In some programs money and release time seem to have created more problems than they solved. It is more important to envision and work toward cultures in which teacher collaboration and teacher leadership in career development are supported at all levels. Mentors should not be burdened with more responsibilities than they can carry" (Wildman et al., 1992, p. 212). When a mentor program is mandated to meet state reform the focus is often too narrow to be successful.

This research is valuable in structuring a mentoring program because it not only "demonstrates the various ways that mentors, when given the opportunity act on the basis of their own beliefs and knowledge, attend to the needs of the beginners and their school contexts and cultures." (Wildman et al., 1992, p. 212). The researchers felt that time was the most valuable resource that needs to be written into a mentoring program. Providing time for the mentor and mentee to inner act during the school day, not just before and after school, as well additional professional days will lead to a successful mentoring program.

Harry S. Williams and Osman Alawiyre with the Department of Curriculum and Supervision at Central Washington University conducted a study on mentoring in an undergraduate teacher education pilot program. The researchers were interested in investigating a pilot program between Central Washington University and Public 
Elementary School PartnershipGroup to prepare students in teacher education to become teachers. It is thought that public schools partnering with universities in teacher preparation will better prepare teachers for today's schools. This is much like the idea of curriculum alignment with mandated state proficiency tests only in this study the university is looking for ways to align its teacher education requirements with realistic expectations their students will need when they enter the profession.

There is not a clear research question in this study but the researchers do state the purpose of this study was "to determine whether the overall intent of the year long internship to integrated teaching practice with the study of the professional courses yields benefits as perceived by the pre-service students and master teachers" (Williams, \& Alawiye, 2001, p. 230). The researchers do not state the school year in which they gathered data for this project. The pilot program operated with certain assumptions concerning the needs of students preparing to be teachers. The greater the time spent in field experience the better prepared the student will be when they begin their first year of teaching. Students need to have knowledge "about teaching and the ability to teach under real time constraints" (Williams, \& Alawiye, 2001, p. 229). Partnering with a local school district will better prepare a student to be a teacher. The researchers felt that the best teacher training is hands on in a laboratory setting and the best place to get that type of experience is in a real classroom.

The method used to collect information for this project was done using a Professional Partnership Program (PPP) survey questionnaire. The questionnaires were 
administered two weeks prior to the end of the yearlong study. The researchers used a five point Likert scale to organize the data gathered from the questionnaires. Reliability of the instrument used was tested using SPSS reliability to run a frequency analysis. This is a appropriate test to use for this type of survey but because of the small sample size participating in this study, 13 pre-service students and an unnamed number of mentors. This was a qualitative inquiry because it was presented using primarily verbal data supplemented with numerical data from the tallying of the answers on the questionnaires. This study was done with one collection period by the researchers.

The researchers give specific details on how both the pre-service and master teachers responded to the questionnaires. The conclusion of the study resulted in specific recommendations The three strengths of the program were; it gave an opportunity for different teaching styles to be observed; secondly, the pupil-teacher ratio was lower than the norm because there were two adults in the room and students in the teacher education program had the opportunity to experience what an entire year was really like not just the snapshot of a quarter or semester as in the traditional student teaching experience.

Where there are strengths there were also some weaknesses. The first was confusion in the communication between all parties involved in the study; second, the methods used for assessment overwhelmed the participants and last, although the university was involved in this study some of the professors were unwilling to make accommodations for the students in the pilot program when it came to class scheduling. All involved in the study felt that in the future the university should put their expectations in writing making them very clear, key people should meet monthly and the key courses required of 
the participating students should mesh with the schedule of those students in the public school pilot program.

There seemed to a lot of potential in this study but the outcomes did not meet the expectations. The data needed to be gathered more frequently and compared to data from previous years. This research would have more credibility if it were a longitudinal study.

Gilles is an Assistant Professor in Literacy/Language Arts at the University of Missouri. She has an interest in supporting new teachers. Cramer is Director of MU Partnership for Educational Renewal at the University of Missouri, Columbia. Her interests lie in university-school partnerships and long-term teacher development. Hwang is an Assistant Professor of Reading in the Division of Education of West Texas A \& M University. She takes a holistic view of literacy instruction, literacy development of ESL students and multicultural education.

As teachers develop in their profession they seem to progress through three stages; first, survival, keeping one step ahead of the students, paperwork and all the many facets of teaching that you never learn until you are in the trenches, second, comfort begins to be demonstrated in the classroom and more attention is paid to individual students and less to surviving, and the third stage of mastery is where all areas are functioning smoothly both in the classroom and the school environment in general. It is the survival stage of a teacher's career that is the focus of this study. This study centers on the Teaching Fellowship Program, which "is part of a Partnership for Educational 
Renewal at the University of Missouri” (Gilles, Cramer, \& Hwang, 2001, p. 90). At the time of this study there were twenty-two public schools involved in the Teaching Fellowship Program. This "program began as a pilot in 1995 with two fellows at one elementary school. It has since expanded to 54 Fellows in nine school districts (suburban and rural) across the state" (Gilles et al., 2001, p. 90).

This study was designed to build on previous research by Runyan in 1997, 1998 and 1999, which focused on the needs of the pre-service teacher. The questions that identified the goals of this research by Gilles et al. in 2001 are:

1. Over a five-year period, what do the Teaching Fellows consider their greatest concerns in teaching?

2. How do their concerns compare with the model set forth by Runyan?

"In order to find information to better understand the characteristics of the Teaching Fellows, survey data were examine and described qualitatively" (Gilles et al., 2001, p. 90). The surveys were distributed in November/December of the teachers first year. The first year when only two Teaching Fellows were involved in the study the return rate was $100 \%$ in the following years the percentages varied from $56 \%$ to $96 \%$ as the program began to expand. Examples of questions asked in this study are:

- When I think of teaching, I am most concerned about...

- What have you found to be the most challenging aspects of teaching? 
"Since the entire population of the Teaching Fellows was used, statistical tests were not appropriate" (Gilles et al., 2001, p. 91). Answers were analyzed using a four-phase methodology. "In the first phase we combined all the statements from both question one and question two. Then we did a content analysis using a constant comparison method of each unit of data. To insure trustworthiness, another researcher, (a peer debriefer) independently used the same data set to create categories" (Gilles et al., 2001, p. 91). Discrepancies were discussed and modifications if necessary were made that time.

The findings broke down into three categories; concerns benefiting the self or survival, concerns about the situation of the task or mastery and concerns about student needs, the impact they were having on their students. Classroom management or discipline did not seem to be a major concern to these Teaching Fellows, which was a surprise to the researchers. In previous research by Runyan in 1999 this was a major concern of the beginning teacher. Possible explanations for this by Gilles et al., (2001) are:

1. Teaching is not developmental and there are not identifiable stages, or theses stages have been incorrectly identified.

2. These Teaching Fellows are a select group.

3. The fellows have a mentor in the true sense of the word. The mentor does not have a classroom. Instead $1 / 3$ of the time is devoted to working with the fellows, $1 / 3$ of the time is working in professional development within the school and $1 / 3$ of the time is devoted to university duties.

4. The Teaching Fellows have relevant coursework that is fully and carefully integrated into the practice life of the teachers.

5. There is the possibility that this group is a cadre. They meet bi-monthly and 
realize that there are other people going through the same issues. (p.95)

The researchers determined that over time "the Teaching Fellowship program is a strong program that uses mentoring, a cadre and pertinent coursework to guide teachers' first steps. In addition it is a promising vehicle for accelerating the developmental growth of new teachers, and perhaps, keeping them in the profession" (Gilles et al., 2001, p. 96).

Jean Boreen is a teacher at Northern Arizona University in the English Department. Donna Niday is a teacher at Iowa State University, Ames, IA. Boreen and Niday have co-authored a book on mentoring along with J. Potts entitled Mentoring the beginning teacher: Guiding, reflecting, coaching. The article reviewed by this author is entitled Breaking through the isolation: Mentoring beginning teachers by Boreen and Niday.

The purpose of the research was to determine the potential for the use of technology, specifically e- mail, for mentoring new teachers. In their research they used mentoring with pre-service teachers and professionals already in the field. The goal for researching in this manner was to test the effectiveness of mentoring through technology as a way of easing the isolation felt by teachers in their first year of teaching. Pre-service teachers and mentors did not work in the same school districts. The researchers felt that since the mentor teacher was not in the same school district as the pre-service teacher a dialogue might open up that would be non-threatening to both parties. The researchers view mentoring as a "two-way exchange of listening and questioning and argue that this 
interaction should begin before the beginning teacher's first entrance into the school" (Boreen, \& Niday, 2000, p. 153). The project's four goals were to encourage students to dialogue with experienced teachers using the language of the profession, learn from mentor teachers in the same subject area and circumstances, provide models of collaboration they could transfer to use in their own classrooms, and encourage the use of technology by the pre-service teachers.

The researchers first goal was to locate university students and veteran teachers to participate in the project. The project consisted of two parts. In the first part four teachers, two from Iowa and two from Arizona, mentored 60 students, 28 from Iowa and 32 from Arizona, for one semester. Boreen and Niday do not state in the research what year this project took place or the gender of all participants. Students and mentors were than paired with common interests in mind. The remaining goals for the project evolved as the students and mentors exchanged e-mails through out the semester. When the semester was over the researchers assembled the data. They decided to base their research on one mentor teacher and two pre-service teachers for the purpose of their documentation. The researchers felt the veteran teacher had done an outstanding job with her communication and the techniques she used with her pre-service teachers. The veteran teacher met the researchers goals because she mentored by modeling, illustrating, questioning, qualifying and reflecting. It was noted that the veteran teachers "care with language invited pre-service teachers into the profession" (Boreen, \& Niday, 2000, p. 158). 
"The second part of the study paired students from Iowa and Arizona according to common interests perceived through the topics chosen for unit planning" (Boreen, \& Niday, 2000, p. 154). The unit planning was a piece of the data from the first part of the study. At the end of the semester the researchers assembled their data and reported on one pair of students from the peer mentoring documentation. This pair was working on a unit plan for a middle school English class. There was a lot of give and take in their correspondence with both wanting to encourage the other in a way that was constructive.

The results of both parts of the study were disappointing to Boreen and Niday. They had hoped that more of the students would develop a collegial type of relationship through this e-mail correspondence than the data indicated. Many of the students in the peer mentoring indicated they felt more comfortable sharing with their peers at their own university than reaching out to someone they did not know in another state.

The goals of this project were met to varying degrees. The researchers noted the length and frequency of correspondence in both parts of the study were less than they had anticipated at the onset of the research. The degree to which a participant felt comfortable with technology appeared to be an indicator to how successful they were in maintaining their correspondence. The veteran teachers were corresponding with twentyfive pre-service teachers and all felt they would have been more successful if the correspondence had been one on one. The researchers felt that since they "did observe noticeable benefits from this project, we would encourage methods class teachers across the curriculum to adopt a similar program" (Boreen, \& Niday, 2000, p. 162). In this 
research the student's participation was mandatory and in the future they felt it would be more successful if participation had been on a volunteer basis. The methods used by the veteran teacher in their documentation would be equally as successful in a face-to-face mentoring program as in the use of technology.

The researchers in this project used a qualitative approach presenting primarily verbal data in their documentation. Their method of collection was ongoing. Specific questionnaires were not used but the recorded dialogue was saved throughout the entire project. Although the researchers felt good about their results this researcher feels their study would have been stronger and have more credibility if the data they collected had been measured in some format. This would have been a stronger study if more pairs were followed throughout the year for some comparison studies

Tom Ganser, Ph.D. gave a speech, on April 29, 1995 at a conference for Middle School Educators. Dr. Ganser conducts mentor-training workshops for school districts beginning the process of mentor training for those mentoring new teachers. He also directs the longest continuously running mentor program for teachers in the United States. The speech was targeted to middle school administrators attending the abovementioned conference.

A mentor is important to the new teacher even when the administrator in the building has an open door policy and encourages new teachers to come to him or her with their problems. No matter how open that door appears most novice teachers are not 
going to spill their hearts about their failures and concerns in the classroom to the same person that will be evaluating their performance through out the school year. The beginning teacher needs someone they can be transparent with about their problems and that person should not be the same one responsible for their evaluation. This is one of the arguments behind the need for a quality-mentoring program within today's schools.

Resources need to be considered when planning a mentoring program. An administrator may be called on to cover classes so the mentor is available to the mentee. If this is something administrators are willing to do it needs to be written into the program. If additional training and workshops are part of the program is money available in the district to cover the pay for substitute teachers? Time is a key in mentoring, the relationship does not just happen; it needs time to be established. When writing a good lesson plan the outcomes to be assessed and the tool to be used for assessment are decided in the beginning, the same is true of a quality-mentoring program. "Naturally, the feedback sought should be related to the goals and objectives established" (Ganser, 1995, p. 6).

All aspects of the program need to have clear definitions of each person's role and responsibilities in the mentoring program. At the same time that the above are being clearly defined their needs to be room for flexibility within the programs to allow for the individual needs and concerns as they occur through out the year. It is important to not only allow time to talk about concerns but also to share with each other what is working well for the individuals involved in the program. How many meetings will be included in 
the program? What about classroom visitations will there be release time for the visitation and/or follow up time after the visitations? Will the mentor be willing to be observed by the mentee modeling a solution to a problem the new teacher may be having in her classroom? Should the new teacher be required to keep a journal for the mentor? What about workshops, will it be required that they attend them together or separately? Will it be the mentors' job to evaluate? What about confidentiality? The above are just a sample of some of the questions that Ganser advises an administrator addresses when sitting down to plan a mentoring program.

Once the guidelines are in place the administrator will need to set guidelines for training mentors. It is important to have a group of teachers trained to mentor at the end of one academic year prepared to work with any new teachers hired over the summer break. Ganser said to the administrators that mentors would need to be knowledgeable in their content area. A mentor needs to have acquired the skills to be good at conferencing with another adult. Ganser recommends knowledge of the skills used by administrators when doing clinical observations for the purpose of evaluation. Mentors need to be experienced teachers, usually those with between eight and fifteen years of teaching make the best mentors according to Ganser. "If mentors have just a few years of teaching experience, beginners may question their expertise, but if mentors are nearing retirement beginners may doubt their ability to remember what it was like to be a new teacher" (Ganser, 1995, p. 10). Mentors should be considered as one part of the team when it comes helping new teachers. The mentor should not be the only person on staff reaching out to assist the beginning teacher. 
The author of "The benefits of mentoring", John H. Holloway, is the Project Director for Educational Testing Service, the designers of Pathwise and PRAXIS programs. Pathwise is the program used by mentoring programs in Ohio as part of their Entry Year Teacher Program. The PRAXIS III is the observation portion of the PRAXIS experience that the entry teacher in Ohio will be required to pass before receiving a fiveyear license to teach.

The focus of this article is on the need for mentors to have some formal training for a program to be effective. "To be effective, mentoring programs need focus and structure" (Holloway, 2001, p. 85). Mentors should be active in furthering their own professional development. Keeping in mind that the mentor is now a teacher of a teacher, "appropriate training for the mentor's expanded role improves the quality of a mentoring program" (Holloway, 2001, p. 85). Mentors have "found that working with beginning teachers engaged them in reflection about their own instruction practices" (Holloway, 2001, p. 86).

California has developed their own program for mentor programs, the California Formative Assessment and Support System for Teachers. "Trained mentors help novice teachers plan lessons, assist them in gathering information about best practices, observe the new teachers' classes, and provide feedback. The novice teachers reflect on their practice and apply what they learned to future lessons" (Holloway, 2001, p. 86). 
Pathwise is a "formal induction process developed by the Educational Testing System for prospective teachers and their mentors" (Holloway, 2001, p. 86). In a study conducted by Carmen Giebelhaus, of the Educational Testing Service and Connie Bowman of the University of Dayton the researchers came to the conclusion "that prospective teachers who were assigned mentors trained in using this discussion framework demonstrated more complete and effective planning, more effective classroom instruction, and a higher level of reflection on practice than did new teachers whose mentors had received only an orientation program" (Holloway, 2001, p. 86).

Holloway comes to the conclusion in this article that "a focused, systematic mentoring program has a positive influence on the performance of new teachers - and is advantageous to mentors as well" (Holloway, 2001, p. 86).

In the 1999 National Education Associations Foundation for the Improvement of Education (NFIE) prepared a pamphlet entitled Creating a Teacher Mentoring Program for school districts to use as a guide when planning a mentoring program. It gives an overview of "the issues and questions that school districts, teacher associations, and universities should consider when developing new or existing mentor programs" (NFIE, 1999, p. 1). A mentor is the person the entry year teacher can count on to make sense of the parts of teaching that often seem overwhelming in the first few years of teaching. Mentoring not only is seen as a way to help new teachers as they enter the profession but also too encourage them to stay beyond those first couple of years. "The National Center for Education Statistics reports that 9.3 percent of new teachers leave the profession after 
only a year (1994-95 data)." (NFIE, 1999, p. 4) In urban school districts where mentoring has been in place for several years, for example Columbus, Ohio, the percentage of teachers remaining in the profession is higher than the national average. Mentoring is a win, win situation for the school district that carefully plans its mentoring program. Mentoring not only benefits the entry year teacher but, "a majority of those teachers who provided mentoring assistance at least once a week also reported substantial improvements to their practice." (NFIE, 1999, p. 5) This paper makes clear that what is offered is ideas that have worked but that there is "no single program design that meets the needs of every district in every situation." (NFIE, 1999, p. 5)

Traditionally teachers have worked in isolation so when an experienced teacher decides to take on the responsibility of mentoring it is important that they know in the beginning they will not be working alone. Mentoring is a partnership and both parties must be open to developing a relationship. Mentoring requires time outside the classroom and often the regular school day, for meetings, observation and sharing. In an ideal situation the mentor will be given release time to observe the mentee at work in his or her classroom. This is usually not the case so time must be taken from the mentors planning time to meet with the mentee and observe them teaching. Time needed for sharing and reviewing is delegated to before and after school. It is recommended in this paper "that teacher associations conclude written agreements to provide mentors and protégés with adequate opportunities to observe one another, model good teaching, and discuss instructional strategies and resources." (NFIE, 1999, p. 7) 
Confidentiality is an area that needs to be addressed in the policy making of a mentoring program. A protégé needs to feel confident that the relationship with their mentor remains between the two of them to enable the protégé to be open in the strengths as well as areas where they may feel they are loosing ground with their class. Some districts feel the need "to include formal memoranda of agreement in which districts and the local teacher associations consent to keep confidential all proceedings between mentors and their protégés.” (NFIE, 1999, p. 8)

The NFIE believes the success or failure of a new teacher in the profession often hinges on the initial job assignment that is given the new teacher. "Even the best mentoring programs can be made better if teachers, teacher associations leaders, and school administrators agree to change traditions that assign the most experienced teacher to advanced placement calculus, while the newest faculty member struggles to teach remedial algebra to students with learning difficulties." (NFIE, 1999, p.9) It is suggested that when the experienced teacher taking on the more challenging classes they can model to the younger teachers they are mentoring how to maintain control and teach the more challenging classes.

First generation mentoring worked more as a buddy system; the only requirement to be a buddy teacher was to have more experience in the school than the new hire and if it was possible to be teaching the same grade level or subject. Second generation asks more of the mentor so in most mentor programs some formal training is required. A mentor "possesses the confidence and presence to offer counsel to other adults." (NFIE. 
1999, p12) "The qualities of effective mentors - as identified by participants in mentoring programs nationwide - may be organized into four general categories: attitude and character; professional competence and experience; communication skills; and interpersonal skills. Together with a willingness to serve and a vote of confidence by colleagues, these characteristics comprise guidelines for selecting mentors." (NFIE, 1999, p.13) The method for selecting mentors will vary from school district to school district but the one characteristic that is consistent is the need for definite criteria for the selection process. As the pool of experienced teachers diminishes the challenge will be in finding teachers that meet the criteria and are willing to mentor. Some school districts are meeting this challenge by relieving a teacher or teachers of their classroom position for a school year to allow them to mentor multiple new teachers. This method has proven successful in urban schools allowing the mentor teacher to work in multiple buildings; a method that would not work if the mentor still had teaching responsibilities. School districts need to offer some means of an incentive, which needs to a part of the negotiated agreement within the district. The stipend needs to be fair but at the same time it is important that it not be so large as to be the only reason a teacher would want to mentor. "Teachers and school administrators involved in successful mentoring programs emphasize that training for mentors must be ongoing." (NFIE, 1999, p.17) Not only do the mentees need mentoring, but also does the mentor, which is why the more successful mentoring programs have a designated lead mentor to mentor the mentor. Mentors are not administrators and a successful program will protect the mentor from administrative duties. Schools "must recognize that a person may have a leadership role on the faculty without being part of the administrative staff." (NFIE, 1999, p.17) 
Experienced mentors have discovered that protégés pass through three basic stages in the beginning of their career. "The first stage focuses on practical skills and information - where to order supplies, how to organize a classroom, where to find instructional resources, what kind of assistance the teacher association can provide, etc. During the second stage, mentors and protégés can concentrate more intently on the art and science of teaching and on polishing classroom management skills. In stage three, the focus shifts to a deeper understanding of instructional strategies and ongoing professional development that is based on the assessed needs of the students." (NFIE, 1999, p.20) Mentoring is one part of the total picture of integrating the new teacher into the profession. Each mentoring program will be shaped by the nature of the district and the policies set forth by the individual school boards. "At the program level, evaluation and careful documentation help both to improve the effectiveness of mentoring and to justify the investment to policymakers and educations stakeholders." (NFIE, 1999, p. 21)

Eby, McManus, Simon and Russell (2000) conducted a study on protégés perspective regarding negative mentoring experiences. The authors of this study are employed at University of Georgia, University of Tennessee and University of Maryland. This researcher found no documentation in this article that would lend credibility to their qualifications in this area.

The authors feel that mentoring programs are implemented with good intentions. Professionals who are mentored usually have a greater job satisfaction and less turn over 
in positions. Not all mentoring relationships are pleasant; in fact it has been discovered that some are abusive and dysfunctional. The authors of this research decided to focus on the negative aspects of mentoring. The research was driven by the following questions:

1. What percentage of protégés report having at least one negative mentoring experience?

2. What are the categories that best describe the negative mentoring experiences reported by the protégés?

Since the methodology being used in this study is quantitative the authors also included in their report the following three hypotheses.

1. Protégés will be more likely to report that their mentor had a dissimilar background when describing their most negative me ntoring experience compared to their most positive mentoring experience.

2. Protégés will be more likely to report that their mentor had dissimilar attitudes, values, and beliefs when describing their most negative mentoring experience compared to their most positive mentoring experience.

3. Protégés will be more likely to report that there mentor was a supervisor when describing their most negative mentoring experience compared to their most positive mentoring experience. 
The setting for this study was an unnamed university in the southeast. The article is recent being published in 2000 but the date of study is unnamed in the documentation. "Surveys were administers in two executive development programs. Each program participant was given a survey packet containing a survey to complete themselves, as well as 10 surveys to be distributed to their subordinates, peers, and higher level managers" (Eby et al., 2000, p. 7).

The results of the first research question yielded the answer that $54 \%$ of those mentored reported being in at least one negative mentoring relationship. "The content analysis procedure yielded five broad sub categories or meta themes of negative mentoring experiences: Match within the Dyad $(n=46$, Distancing Behavior $(n=41)$, Manipulative Behavior $(n=39)$, Lack of Mentor Expertise $(n=29)$, and General Dysfunctionality $(\mathrm{n}=13)$ )" (Eby et al., 2000, p. 10). The above results answered the second research question.

No support was found in the analysis for hypothesis 1 . Hypothesis 2 was supported and hypothesis 3 was not supported.

It needs to be pointed out "caution should be exerted in interpreting our findings" (Eby et al., 2000, p. 17). Mentors were asked to focus on their negative not positive experiences of mentoring. The subjects were mostly white males. There was no follow up in the method of data collection. In regards to the methodology used, the researchers "chose to obtain narrative self-report accounts of negative mentoring 
experiences. While this provides a rich database to draw upon" (Eby et al., 2000, p. 18) it draws from the credibility of the research.

The journal article Teachers Training Teachers focuses on the Poway Professional Assistance Program a teacher induction program designed to assist teachers during their first two years of teaching. Susan Van Zant is principal of Meadowbrook Middle School. Don Razska is president of the Poway Federation of Teachers. Charlotte Kutzner is a program director and a teacher consultant for the Poway Professional Assistance Program. Teaching is a profession where after a semester or quarter of actual on the job training known as student teaching the new teacher is thrust into the job expected to have all the knowledge required to handle the same on the job responsibilities as the professional that has been on the job for a number of years. It is a sink or swim type of philosophy that programs such as the Poway Professional Assistance Program plan to change. This program has been in place since 1987 and more than 900 teachers have benefited from this type of teacher induction program. "The philosophy of the program is to tailor feedback and support to the individual teacher's needs" (Van Zant, Razska \& Kutzner, 2001, p. 23). The teacher consultant must have five years of teaching with a variety of experiences within the district. The teacher consultant is full time "working with a maximum of 15 first year teachers, the consultant completes the contract requisite of six formal, written observations. It is expected that the consultant will have more than 40 hours of contact time throughout the year" (Van Zant et al., 2001, p. 23). During the first year the evaluation is the responsibility of the teacher consultant transitioning to the responsibility of the site principal during the second year. 
The second year is individualized with the strengths and weaknesses being addressed on an as needed basis with the teacher consultant and site principal. Continued professional growth is addressed during this second year. This program is very similar to second generation mentoring in that it addresses the needs of the new teacher for ongoing support. This program is very different in the way the mentoring of entry teachers is being addressed in Ohio in that the mentor in this program works more in the capacity of an administrator than purely as a mentor apart from assuming any administrative responsibilities.

The education profession in Canada is facing some of the same issues of teacher retention as the United States. In the study by Goddard and Foster in 2001 the researchers looked at The experiences of neophyte teachers: a critical constructivist assessment. Goddard is on the Faculty of Education, University of Calgary, Canada. Foster is part of the faulty at University of Manitoba, Canada. Both of the authors of this research have previously published journal articles relating to this topic.

Teachers in Canada are not staying in the profession past the first few years of their careers and research was needed to determine what can be done to turn this around. This research used a collective case study approach. This a qualitative research approach. The overall question behind this research was: "to what extent do neophyte teachers consider themselves prepared for the "real world" of schools?" (Goddard \& Foster, 2001, p. 350). The objectives were "to document the phenomenon of beginning 
teaching experiences from the perspective of the neophyte teacher themselves and to investigate the extent to which beginning teachers perceive pre-service programs to be adequate preparation for the real world of schools" (p. 350). Data for this research was “collected between August 1998 and October 1998 from interviews with nine beginning teachers, as well as from relevant government, school, and school district documents. As the purpose of the study was to gather the perspectives of neophyte teachers, interviews comprised the chief data source" (p. 352). "All respondents were between the ages of 23 and 29 at the time of the study, (seven female and two male), and lived in one of three Canadian provinces: five in Alberta; two in Nova Scotia; and two in Saskatchewan” (p. $352)$.

The results of this study indicate that teachers move through six themes in their first year of teaching and that the transition from one stage to the next occurs at varying stages. One of the sub-areas investigated in this research was the reason the neophyte teacher became a teacher, often there was a teacher in the family background, and if not, they had a teacher in their education they looked to as a role model. The research team for this study consisted of faculty members at Purdue University, West Lafayette, IN. All members have had experience teaching in a public school setting and are currently involved with the preparation of teachers and administrators. Each member has previously done qualitative research individually relating to this current topic.

This purpose of this net study was to evaluate the Beginning Teacher Internship Program project funded by the state of Indiana. "The legislature wants to know if the 
beginning teachers participating in the BTIP (Beginning Teacher Internship Program) benefit from the experiences. Are they more effective than beginning teachers not serving such an internship? Should the state continue to fund the program? Was the program returning value for the money allocated for it?" (Abell, Dillon, Hopkins, McInerney \& O'Brien, 1995, p. 174). The researchers narrowed their research down to the following questions: (1) how do mentors and interns in the BTIP view the program and their roles within it? (2) How and about what do the mentors and interns in BTIP interact? (p. 174).

The methodology used in this research was qualitative. The researchers used a "phenomenological theoretical perspective while interviewing participants in BTIP" (Abell et al., 1995, p. 174). The actual academic year that this data was gathered is not reported in this article. For the purpose of this researcher some of the historical data is dated but the results have validity in light of current research being done in this area. The schools involved in this study were "four elementary, three middle, and four high schools from four Indiana school districts. The school district sites were selected to represent a balance of socioeconomic and academic levels as well as both urban and rural communities (p. 176).

The results of this study after within and cross-case analysis were narrowed down to "three overall findings" (Abell et al., 1995, p. 178). First it was discovered "that mentors believed that working with beginning teachers was important; they believed it was their responsibility to their individual school system and to the teaching profession to get new teachers off to a good start" (p. 178). The second discovery was that "mentors 
did not see themselves as evaluators" (p. 179) but as being available to offer help to the interns. The third result was that "interactions between mentors and interns facilitated the development of mutual respect and trust that bind mentor and intern together" (p. 179).

A key ingredient to the successful mentoring program is thought to be related to mentoring relationship, which was the topic of research for Tammy D. Allen and Mark L. Poteet in 1999. Allen and Poteet (1999) felt since mentoring was becoming more widely accepted in the business community further investigation should be made on this topic. Allen and Poteet have published numerous journal articles on the topic of mentoring in the business related professions. This research was not about mentoring in the area of education but this researcher felt that it still had valuable input on some of the characteristics of a mentoring relationship. "This article presents the results of a qualitative study that investigated the characteristics that the ideal mentor should possess and easy that both mentors and protégés can make mentoring relationships most effective" (p. 59). It is thought, "the effectiveness of any formal mentoring program may hinge on the characteristics of the individual mentors who participate in the program" (p.60-61). Allen and Poteet posed the following two research questions in this study: 1. What are the ideal characteristics that a mentor should possess? 2. What can mentors and protégés do to make the most out of the mentoring relationship.

Allen and Poteet (1999) developed their study using a semi structured interview approach to gather data. This method was used "because a quantitative, survey-driven approach limits the information gathering to only those items or issues that are included 
on the questionnaire" (p. 63). The researchers did not want to limit the input of data because of the limited research already available on this subject. A drawback to this method was the possibility that the researchers' value systems, beliefs, and academic interests may unduly influence conclusions drawn from the data (Van Maanen, 1979). The mentors in this study had volunteered within their organizations to be mentors; they were not assigned by their respective organizations. Five organizations were used in this study, although they were not named specifically they represented municipal government, health-care, financial, communication, and manufacturing organizations. The companies all had greater than $\$ 50$ million in annual sales and 250 or more employees (Allen \& Poteet, 1999). Twenty-seven mentors were identified and agreed to participate in this study, fourteen women and thirteen men. The data was collected through a semi structured personal interview, which lasted about an hour with each person.

Data was analyzed using a three-step method. Comments from the interviews were analyzed and broken down into various dimensions. Dimensions were first broken down into broad categories and narrowed down as each step was analyzed.

Characteristics that rose to the top were "listening and communication skills, patience, knowledge of one's company and industry, and the ability to understand others" (Allen \& Poteet, 1999, p.64-66). Establishing an open communication system was mentions by over $50 \%$ of the participants in this study.

Allen and Poteet (1999) wanted this study to "extend mentoring literature by investigating the perceived characteristics of an ideal mentor and identifying ways that 
mentors and protégés could make the most of their mentoring relationships" (p. 68). The researchers would like to see some quantitative research done on this topic in the future. It was suggested by the results of this research when a mentor is deficient in a particular skill needed to be a mentor that they be provided with training to be a better mentor once they have been chosen to be a mentor.

Allen and Poteet (1999) further determined that open communication is a key to developing good organizational relationships in a mentoring situation. The researchers felt longitudinal studies might be effective in determining how these relationships develop. The policy and procedures of a mentoring program need to be written down so that every one is on the same page. Goal setting and expectations are important at the onset of a mentoring relationship. 


\section{CHAPTER III: Procedures and Results}

\section{Presentation of the Problem}

A large percentage of the research currently available on mentoring, places the focus on the individual components of a successful mentoring program. The implementation of a mentoring program requires a school district to look beyond the obvious: lack of time, compatibility, and mentors role within the system to what will be required of a mentor to earn the title mentor. The Ohio Department of Education links mentoring of new teachers to licensing so this person known as mentor is a key person in the future of the professional educator. This concept of mentoring, also referred to as second generation mentoring, can place a heavy burden on the teacher who is at the same time handling all the responsibilities of their own classroom and often mentoring with very little guidance as to what their responsibilities are within the district.

Ohio's new Teacher Education and Licensure Standards are "designed to strengthen Ohio's teacher preparation, achieve higher standards, and intensify professional development. The new standards require successful performance on the part of beginning teachers. Section 3301-24-04 of the standards declares "the Entry Year Teacher (EY) Program shall include both a formal program of support, including mentoring to foster professional growth of the individual, and assessment of the performance of the beginning teacher" (Ohio Department of Education, 2002). 
When offering guidelines to mentors the Ohio Department of Education states:

Mentor teachers work continuously with EY teachers to enhance their professional growth and understanding of the planning, preparation, and presentation of various learning activities, and the ways to assess

such activities. Mentor teachers receive training in how to support and guide teachers through the use of a system such as Pathwise. Like PRAXIS III, the Pathwise Observation System was developed by the Educational Testing Service to serve as a framework whereby mentor Teachers could provide feedback and prepare EY teachers for performance Assessment.

The requirement that mentors be trained in Pathwise raises the question whether or not the professional actually doing the mentoring agrees that Pathwise training is beneficial when mentoring the entry year teacher. This researcher received a list of all the Pathwise trained teachers in a large city school system in Ohio and presented them with an open-ended survey to find out how they felt the training helped them when mentoring. The researcher then assembled the data and reported the findings from the surveys returned.

\section{Presentation of the Hypotheses}

This researcher was interested in finding out if the mentor training required by the district to become a mentor was thought to be helpful when assigned an entry year teacher to mentor. An open-ended survey was constructed to test the following hypothesis: 
Ho: There will be no significance difference in how the mentors viewed their training as an asset when assigned an entry year teacher to mentor.

\section{Subjects}

The subjects who participated in this research all have been trained in Pathwise for the purpose of mentoring entry year teachers within the district and/or interns for a neighboring university. Ninety-one surveys were distributed within the district to teachers assigned to elementary, junior high and high school buildings. Administrators who had recently been teachers were also included in this study. This district employs 236 classroom teachers, 24 special teachers (art, music, health and physical education), 45 intervention specialists and seventeen administrative personnel. Of these $97.2 \%$ are Caucasian, $2.8 \%$ are other races, $23.7 \%$ are male and $76.3 \%$ are female.

\section{Variables}

\section{Independent Variable}

The independent variable in this study is the fact that not all those surveyed had been assigned to mentor an entry year teacher. Some had been trained in Pathwise as part of the mentoring process in an earlier pilot program or as part of their university program as an intern. All were at various stages in their teaching career with many different types of job assignments. 


\section{Dependent Variable}

The dependent variable in this study is that all were Pathwise trained and currently employed by the same large city school district in Southwest Ohio.

\section{Procedures}

This study was conducted through an open-ended survey to teachers and administrators in the school district where the researcher is employed. A cover letter (Appendix A) and the survey (Appendix B) were delivered personally or through intradistrict mail. The survey was sent within in the first nine weeks of the school before the winter break. Pathwise training as well as Ohio First is referred to in the survey. Ohio First is a requirement (Appendix C) put in place by the district of employment. Ohio First is an extension of Pathwise, which includes a box of detailed activities for the mentor and the entry year teacher to complete in preparation for the PRAXIS III assessment using the same nineteen criteria as Pathwise and PRAXIS III.

\section{Results}

Ninety-one surveys were distributed and fifty were returned to this researcher. The return rate of $54.9 \%$ was a good rate of return for this study. The surveys were then divided into two groups: those that had mentored and those that had not. The results will be reported in two categories. 


\section{Pathwise trained but never assigned to mentor.}

Twenty-four of the responses received were from teachers and one current administrator that had been trained but never assigned a mentor. The years of experience in this group ranged from three to twenty-seven years of teaching. The administrator had taught four years and been an administrator for eight years. The average years of experience for this group was ten years. The administrator had an interesting comment about not being assigned to mentor, "Have not been officially assigned any teacher to mentor, however that is what administrators do (at times) anyways." In this group none were trained additionally in Ohio First. The responses received in this group were primarily from elementary teachers, two from special education, four from special areas (art, physical education and conflict management), two from junior high, two from high school and one assistant principal at the elementary level.

In answer to the question: "Do you believe you have been or currently are a better mentor because of your formal training in Pathwise and/or Ohio First?" Interestingly enough many of the respondents in this group had a comment though not a rating on this question. One respondent rated it a three, on a scale of, 1 to 5 with 1 representing strongly disagree and 5 representing strongly agree, along with the comment "I think that the training is necessary because of the requirements that beginning professionals are expected to meet." This same person had twenty-seven years of experience. Another respondent felt "it would be if I were assigned teachers." Many of the respondents gave a rating, with the average being a three for the above question. This researcher does not feel that with this sample group the rating adds any validity to the study if the respondents have not mentored. 
In the short answer section of the survey there were two questions that will be addressed separately. The first being "How do you feel the training in Pathwise and/or Ohio First did or did not help you to be a better mentor to the entry year teachers and/or teachers new to your district?" The following is a sampling of the responses received to this question:

1. It helps know the expectations and process of evaluation a student teacher or new teacher during their first year.

2. Pathwise training has enabled me to effectively work with interns because I understand how they are supposed to be evaluated.

3. Pathwise gave clear guidelines.

4. My feeling is Pathwise training made me more aware of the overall teaching strategies. As far as mentoring, you have to first be an open person who will share ideas and thoughts.

5. It helped me look at the black and white keeping emotions out of mentoring . Also keeps positives above negatives.

6. The training was beneficial to me because I built a better relationship with an individual who was tough to open up to and we shared rooms. I feel that after five years that our relationship is built stronger due to that program.

7. The training explained the criteria that entry year teachers are expected to master.

8. It has assisted me to guide new teachers through planning, instructional techniques and maintaining classroom management.

9. I think that I gained some insight about the new standards through this training but have not had the opportunity to use it yet.

10. Even though I have not officially mentored, I think it can help give focal points for mentors to stress with the entry year teacher. 
The second question in this short answer section was: "What, if any experiences did you encounter, that were not covered in your formal training that you think would help future mentors?"

1. I work with a team of teachers that all help each other. You need to work with people who are willing to share ideas, materials and techniques as well as letting you observe them teaching.

2. Criticism from mentor when her position is based on her opinion not fact has no place in the mentoring program.

3. Since I was the mentee being helped by my mentor, I feel they should better train the mentors with questions to ask and give them ideas to work on with that new teacher.

4. I think that mentors need to remember what it's like to be new to the profession, building or district. Experienced teachers tend to take some things for granted. One cannot address issues until they have been identified.

This researcher found it helpful that even those teachers that had not had the opportunity to mentor still had some strong opinions about the mentoring program. Many teachers who have not been Pathwise trained have a difficult time understanding the concern of the new professional when preparing for the PRAXIS III observation during their first year of teaching.

\section{Pathwise trained and a mentor within the district of employment}

Twenty-seven of the responses received were from teachers that had actually been a mentor and/or were currently mentoring. The years of experience in this group ranged from five to thirty-one years of teaching. The average years of experience for this group was seventeen years. In this group five were trained additionally in Ohio First. The 
responses received in this group were more spread out but still more elementary teachers responded, three from special education, none from special areas (art, physical education and conflict management), four from junior high, five from high school and one assistant principal from unidentified level. Of the five that were also trained in Ohio First three taught in the junior high, one in the high school and one in elementary.

In answer to the question: "Do you believe you have been or currently are a better mentor because of your formal training in Pathwise and/or Ohio First?" on a five point scale, 1 representing strongly disagree and 5 representing strongly agree, two of the respondents gave this answer a two, eight of them gave it a three, another eight gave it a four, and there were four that responded with a five. The average score was 3.64. Additionally three did not give a numerical rating but responded with a yes. One respondent that gave it a three added the comment, "I did basically all that was expected prior to the program, but Pathwise helped me focus on certain areas."

In answer to the question: "Mentoring involves the development of a relationship between two professionals. Did your formal mentor training help you to develop this relationship?" on a five point scale, 1 representing strongly disagree and 5 representing strongly agree, the answers to this were more spread out numerically with six giving short answers instead of ratings. Three of the respondents gave this answer a one, four gave it two, six gave it a three, five gave it a four and two gave this answer a five. The average score was 2.682. One person left this answer blank, two said "No" with one of those adding "I feel a rapport needs to develop based on common interest and subject 
grade level." There were two that said "yes." Another said, "Somewhat. I probably would not have spent as much time with my mentee otherwise."

In the short answer section of the survey there were two questions that will be addressed separately. The first being "How do you feel the training in Pathwise and/or Ohio First did or did not help you to be a better mentor to the entry year teachers and/or teachers new to your district?" The following is a sampling of the responses received to this question:

1. The training and program gave my entry year teacher and Myself time away from school to share ideas. The program (Ohio First) has a workbook with a checklist that the two would go over together I was also fortunate to have an entry teacher in my own grade level. This is a must.

2. I think I better understand what was expected of them (entry year teacher) so it allowed me to focus on those things.

3. The training helped give guidelines and a timeline for activities.

4. I felt I could be more targeted and direct as I could consult and refer to the goals and make a more valid suggestion.

5. It gives us a format to follow; it forces us to make the time to talk and interact; it gives a common set of expectations for what EYT's know by the end of the first year.

6. The training was extremely boring.

7. It gives a focus for the new teacher and therefore helps you as a mentor to know how to help them. Follow- up or "refresher" training would also be helpful.

8. It helped because it gave me a structured way to observe my entry year teacher. I knew she was competent, this allowed me to be specific about her strengths. 
9. I was much more direct that I have been in the past.

10. Using Pathwise reminds mentors, as well as new teachers, what makes a master teacher, Mentors can improve themselves and their classrooms while assisting new teachers.

11. Learning about the domains was helpful. It also made sharing strengths as well as some areas to work on much easier.

12. It definitely helped because it kept us both focused on the exact area that needed improvement.

13. Experience as a teacher helped me to be a better mentor.

14. To me most of it was common sense. Teachers who should be mentors should already be doing this in their classroom.

The second question in this short answer section was: "What, if any experiences did you encounter, that were not covered in your formal training that you think would help future mentors?"

1. The most difficult part of mentoring is finding time to meet with your entry year teacher. Schedules and after school activities made it difficult to spend time together.

2. Understand that is takes a lot of time to do the mentoring properly.

3. Guiding the mentees on effective use of time and how to get it all done on time.

4 Administrators are responsible for matching mentors with entry year teachers. There is always an element of uncertainty or incompatibility that must be considered. A plan should be made for solving such problems.

5. Teachers that do just enough to get by.

6. I was not given time to observe my mentee. I was able to do it because I had a student teacher.

7. Just stress the "building of the relationship." 
8. The concept or quality of paraverbals isn't addressed in Pathwise. I've learned a lot by observing a master who exudes paraverbals.

9. Pathwise helped us both look at all the teaching skills and work on those that were weak and celebrate the strong ones. So often we know there is something good or needs improvement but we can't put a finger on it. Pathwise put it all in perspective.

10. What to do (as a mentor) if you have worked extensively with an entry year teacher who is not performing well and/or is "getting away" with things that affect his/her job, but that may not be readily apparent to an administrator. (You do not believe this person is effective and/or you strongly feel that a higher up should be aware of specific problems.) How do you handle that?

11. My second mentee was "fired" at the end of the year. I'd like to have had more "say so" (more than Pathwise allows) during the year process. I won't be mentoring again for a while till I get over this "bad experience."

This researcher believes after reading through the surveys and documenting the data and responses of those that have mentored that to some extent the Pathwise training had made mentoring easier for them. Having a common ground to start with facilitated conversation between the mentor and mentee. Pathwise training made it easier to point out the positives as well as the negatives. The hypothesis: There will be no significance difference in how the mentors viewed their training as an asset when assigned an entry year teacher to mentor was proved wrong because the respondents felt that the Pathwise training had made a positive difference in their approach to mentoring. 


\section{CHAPTER IV: Summary and Conclusion}

In conclusion this researcher found evidence that supports earlier research by Bowman and Giebelhaus as well as Little, Moir, Gless and the National Education Association that a successful mentoring program incorporates mentor training into their

program. A successful mentoring program increases the likelihood that a novice teacher will remain in the classroom beyond the first two years of teaching. The literature reviewed as part of this research demonstrated that when a program is driven by requirements coming from a source outside the school district where the program is originating it is more likely to have definite requirements for the choosing of the mentors. The results of the open ended survey conducted by this researcher indicated that mentors felt more comfortable in their position as an advisor to the entry year teacher when there is specific criteria to be evaluated when working with the new teacher. The survey results supported the theory that it is easier to address the entry year teachers' strengths as well as weaknesses when working within the framework of a system such as Pathwise. Mentoring has gone beyond the idea of being a buddy teacher as was found in first generation mentoring to becoming an integral part of both the entry year teacher and the mentor teacher's future professional development. Mentoring and mentor training not only teach the mentor how to observe and evaluate another teacher's methods but also has the potential to cause the mentor to also reflect on their own methods of teaching.

This researcher found as stated above that mentor training is a key to a successful mentor program. The school district surveyed has added the requirement that a mentor 
be trained in both Pathwise and Ohio First to become a mentor for their school district. Ohio First. Ohio First is an extension of Pathwise training which includes a box of materials that the mentor and the entry year teacher work through together and apart. There are ten events and paper work that are required to be completed through out the school year. It is thought by working through these ten events the entry year teacher will be better prepared for their PRAXIS III observation. In a school district that employs 303 certified teachers of the 91 surveys with Pathwise training, only five of the fifty that responded has also been trained in Ohio First. The requirement of Ohio First on top of Pathwise training may cause a problem when the district needs mentors for the entry teachers of the future to meet the requirements set by the state of Ohio. At least one successful mentoring program in the northern part of the state of Ohio when asked about Ohio First training said they opted not to make that part of the requirement because of the cost involved in purchasing the materials and the additional time needed to train the mentors. This is an area where future research could be conducted comparing the ability of a mentor to be a successful mentor with only Pathwise training as compared to one with Ohio First training and all the resources involved when incorporating it into a mentoring program.

This researcher was inducted into the teaching profession without the benefit of the support of first or second generation mentoring. As one that was inducted into teaching by the sink or swim method after only twelve weeks of student teaching mentoring is an area that has been of interest because it is a method that has the potential 
to improve the quality of teaching in the beginning in a way that will encourage the teacher to stay in the profession. If the author were to do continued research on this topic she would compare mentors and their opinions about mentor training with both large city schools and rural schools. Another topic of interest related to this topic would be whether or not the entry year teacher sees the mentor as a key person in their ability to pass the PRAXIS III observation and do more than survive during the first year of teaching.

This researcher was interested in the qualities of a successful mentoring program because they were one the people planning and implementing the program where the survey for this research was conducted. It was thought that release time would be a key to a successful mentoring program and that training would not factor in as the cornerstone of successful second generation mentoring. It is interesting to note that until states began to require mentoring as part of their licensing programs mentoring was often neglected or did not move beyond assigning a buddy teacher. Mentoring is now part of continuous improvement plans being written by many school districts. It would be valuable to research test scores of students whose teachers have been mentored through a program such as Pathwise compared to those who have had a less structured or non-existent mentoring program.

This author agrees with the research reviewed, as well as her own, that a successful mentoring program needs to incorporate formal training into its program. To do so will encourage graduates in the field of education to remain in the profession beyond the first few years. Mentoring of new teachers gives them a firm foundation on 
which to build their career in education. When a person becomes part of the body of Christ, in the church the author attends, they are a assigned a person to mentor them in their Christian walk and Bible study. Just as a new Christian is given guidance the entry year teacher needs the same type of support if they are to continue to grow in their profession. 


\section{APPENDIX A}

November 29, 2002

Dear

I am a graduate student at Cedarville University in the process of completing a thesis on mentoring and entry year teacher programs in the state of Ohio. I have been doing extensive research on the components of a successful mentoring program. A component mentioned repeatedly is the need for a mentor to be trained in Pathwise and/or Ohio First. I, like you, have participated in the Pilot Program through the Greene County Educational Service office and am interested in any feedback you have received from your mentees, as well as your own opinion on formal training for mentors. Please complete the enclosed questionnaire and return it to me in the next few weeks. You may return it to me through intra district mail to Five Points or Wright Elementary School. This would be greatly appreciated.

I know how valuable your time is, especially this year with all the new programs being introduced. This type of data will not only benefit my research but also our profession as we look at what is truly beneficial when we are asked to mentor an entry year teacher for our district.

Thank you,

Linda K. Cernetic 


\section{APPENDIX B}

Background information.

1. How many years have you been a teacher?

2. How many entry year teachers and/or teachers new to your district have you mentored?

3. What grade or subject do you teach?

4. Are you trained in both? If only one is it Pathwise or Ohio First?

Using the following scale with 1 representing strongly disagree and 5 representing strongly agree please respond to the following questions.

1. Do you believe you have been or currently are a better mentor because of your formal training in Pathwise and/or Ohio First?

2. Mentoring involves the development of a relationship between two professionals. Did your formal training help you to develop this relationship?

Please answer the following questions with as much or little detail as you feel appropriate.

1. How do you feel the training in Pathwise and/or Ohio First did or did not help you to be a better mentor to the entry year teachers and/or teachers new to your district that you have mentored?

2. What, if any experiences did you encounter, that were not covered in your formal training that you think would help future mentors?

Thank you! 


\section{APPENDIX C}

\section{Local District Entry Year Program Policies}

\section{Training and Qualifications for Mentors}

Mentors must be trained in Pathwise and Ohio First prior to becoming a mentor for XXX. Mentors must have 5 years of teaching experience, minimum of 3 years in XXX.

\section{Assignment}

Training will be made available through XXX. Teachers meeting the above training and qualifications may apply to be a mentor. Mentors will them be assigned to specific entryyear teachers using the procedure negotiated by the XXX and XXX Education Association.

\section{Confidentiality}

Information obtained by the mentor or the entry year teacher through conversations or direct observation is strictly confidential. Information is not to be shared with other colleagues or administrators.

\section{Roles and Responsibilities of Mentors}

The role of the mentor is to help the entry-year teacher improve his or her professional performance.

- While the mentor is not evaluating the performance of the entry-year teacher for the purpose of employment, the mentor does observe the entry-year teacher's classroom, make analytic judgments based on Pathwise principles, and provide coaching, feedback and correctives to the entry-year teacher.

- The mentor is to also acquaint the entry-year teacher with building policies, procedures, traditions, norms, and idiosyncrasies.

- The mentor will guide the entry-year teacher through the ten events of Ohio First.

- The mentor will complete all required documentation.

- The mentor is to attend and ensure that the entry-year teacher attends the schedules workshops.

\section{Mentor Stipends}

Mentors will be paid according to the stipend in the negotiated agreement.

\section{Professionalism}

The duties of the mentor, including informal mentoring as well as the formal administration of Pathwise and Ohio First, are to be carried out in a thorough and professional manner. Should a mentor perform his or her job in a less than professional manner, he or she risks loss of future mentoring assignments. 


\section{REFERENCE LIST}

Abell, S. K., Dillon, D. R., Hopkins, C. J., McInerney, W., \&

O’Brien, D. (1995). "Somebody to Count on": mentor/intern relationships in a beginning teacher internship program.

Teaching and Teacher Education, 11 (2), 173-188.

Alawiye, O. \& Williams, H. (2001). Assessment: lessons learned from a year long undergraduate teacher education pilot program. Journal of Instructional Psychology, 28 (4), 229-233.

Allen, T., \& Poteet, M. (1999). Developing effective mentoring relationships: strategies from the mentor's viewpoint. Career Development Quarterly, 48 (1), 59-73.

Bird, T., \& Little, J. W. (1985). From teacher to leader.

San Francisco: Far West Laboratory for Educational Research and Development.

Boreen, J., \& Niday, D. (2000). Breaking through the isolation: mentoring beginning teachers. Journal of Adolescent \& Adult Literacy, 44 (2), 152-163.

Boreen, J., Johnson, M.K., Niday, D., \& Potts, J. (2000) Mentoring the beginning teacher: Guiding, reflecting, coaching. York, 
ME: Stenhouse.

Bowman, C. L., \& Giebelhaus, C. R. (2002). Teaching mentors: is it worth the effort? The Journal of Educational Research, 95 (4), 246-254.

Cramer, M. M., Gilles, C., \& Hwang, S. K. (2001). Beginning teacher perceptions of concerns: a longitudinal look at teacher development. Action in Teacher Education, 23 (3), 89-98.

Eby, L. T., McManus, S. E., Russell J. E. A., \& Simon, S. E. (2000). The protégés perspective regarding negative mentoring experiences: the development of a taxonomy. Journal of Vocational Behavior, 57, 1-21.

Entry year teacher guidelines for the state of Ohio. Retrieved May 18, 2002 from http://www.ode.state.oh.us/teachingprofession/teacher/certification_licensure.asp\#3301-24-04

Foster, R. Y., \& Goddard, J. T. (2001). The experiences of neophyte teachers: a critical constructivist assessment. Teaching and Teacher Education, 17, 349-365.

Ganser, Tom. (1995). A road map for designing quality mentoring mentoring programs for beginning teachers. (Paper presented at the Annual Conference of the Wisconsin Association for Middle 
Level Education). Stevens Point, WI, April 29, 1995. (ERIC

Document Reproduction Service No. SP036618).

Gless, J. \& Moir, E. (2001). Quality induction: an investment in teachers. Teacher Education Quarterly, 28 (1), 109-114.

Hart, A. W., \& Murphy, M. J. (1989). New teachers' responses to redesigned teacher work. Paper presented at the annual meeting of the American Educational Research Association, San Francisco.

Holloway, John H. (2001). The benefits of mentoring. Educational Leadership, 58 (8), 85-86.

Kutzner, C., Razska, D., \& Van Zant, S. (2001). Teachers training teachers. Thrust for Educational Leadership, 30 (3), 22-24.

Little, J. W. (1990). The mentor phenomenon and the social organization of teaching. In C. B. Cazden (Ed.), Review of Research in Education, (Vol. 16) 297-351. Washington, DC: American Educational Research Association.

MacArthur, John. (1997). The MacArthur Study Bible: New King James Version. Nashville, TN: Nelson Word Publishing.

Magliaro, S. G., Niles, J. A., Niles, S. G. \& Wildman, T. M. (1992). Teacher mentoring: an analysis of roles, activities and 
conditions. Journal of Teacher Education, 43 (3), 205-213.

Runyan, S. K., Sparks, R., McDougle, K., \& Adams, S. (1997, October). Identification of preservice and early career teacher developmental stages through needs assessment. Paper presented at the annual meeting of Mid-Western Educational Research Association, Chicago, IL.

Runyan, C. K., White, V., Hazel, L., \& Hedges, D. (1998, February). A seamless system of professional development from preservice to tenured teaching. Paper presented at the annual meeting of the American Association of Colleges for Teacher Education. New Orleans, LA. (Educational Document Reproduction Service ED 417 167).

Runyan, C. K. (1999). Mentoring: Aim and assess. Mid-Western Educational Reseracher, 12(4), 14-17.

Slavin, R. E. (1986). Best evidence synthesis: an alternative to metaanalytic and traditional reviews. Educational Researcher, 15 (9), 5-11.

The National Education Associations Foundation for the Improvement of Education. (1999). Creating a teacher mentoring program, 1-25. Retrieved May 18, 2002 
http://nfie.org/publications/mentoring.htm.

Van Maanen, J. (1979). Reclaiming qualitative methods for organizational research: A preface. Administrative Science Quarterly, 24, 520-526. 


\section{VITA}

Linda K. Cernetic grew up in Yellow Springs, Ohio. She graduated from Yellow Springs High School in 1967 and married her high school sweetheart in 1968. They have lived in California, Washington and Ohio. In June 1977 she graduated from Wright State University with a B.S. degree in art education. Additional course work was completed to earn a teaching certificate in special education at Wright State University and the University of Dayton.

Linda has taught at Mills Lawn Elementary in Yellow Springs, Cedar Cliff Schools in Cedarville, Green County Learning Center, and Xenia City Schools and is currently employed by Fairborn City Schools in Fairborn, Ohio. She has taught art, learning disabilities and severe behaviorally handicapped students. She is completing her twenty first year of teaching having stayed home with her children when they were young.

On August 21, 1993 she accepted the Lord Jesus Christ as her savior. January 1994 her husband did the same; this completed the salvation of her family. Linda has three children; Joshua, a police officer, Michaela, a senior at Cedarville University and Faith, a sophomore at Cedarville High School.

Linda is involved in her local church, Grace Baptist in Cedarville. She also serves on the local school board. Linda is pleased to have completed her Masters degree at Cedarville University. 